OPEN ACCESS

Edited by:

Ovidiu Constantin Baltatu,

Camilo Castelo Branco University,

Brazil

Reviewed by:

Slade T. Matthews,

The University of Sydney, Australia

Sumit Sahni,

University of Illinois at Chicago, USA

*Correspondence:

Christoph Küper,

Department of Physiology, University of Munich, Pettenkoferstrasse 12,

80336 Munich, Germany

christoph.kueper@lrz.uni-muenchen.de

Specialty section:

This article was submitted to Integrative Physiology,

a section of the journal

Frontiers in Physiology

Received: 16 July 2015 Accepted: 07 September 2015

Published: 24 September 2015

Citation:

Küper C, Beck F-X and Neuhofer W (2015) Dual effect of lithium on NFAT5 activity in kidney cells. Front. Physiol. 6:264

doi: 10.3389/fphys.2015.00264

\section{Dual effect of lithium on NFAT5 activity in kidney cells}

\author{
Christoph Küper ${ }^{1 *}$, Franz-Xaver Beck ${ }^{1}$ and Wolfgang Neuhofer ${ }^{2}$ \\ ${ }^{1}$ Department of Physiology, University of Munich, Munich, Germany, ${ }^{2}$ Medical Clinic V, University Hospital Mannheim, \\ University of Heidelberg, Mannheim, Germany
}

Lithium salts are used widely for treatment of bipolar and other mental disorders. Lithium therapy is accompanied frequently by renal side effects, such as nephrogenic diabetes insipidus or chronic kidney disease (CKD), but the molecular mechanisms underlying these effects are still poorly understood. In the present study we examined the effect of lithium on the activity of the osmosensitive transcriptional activator nuclear factor of activated T cells 5 (NFAT5, also known as TonEBP), which plays a key role in renal cellular osmoprotection and urinary concentrating ability. Interestingly, we found different effects of lithium on NFAT5 activity, depending on medium osmolality and incubation time. When cells were exposed to lithium for a relative short period (24h), NFAT5 activity was significantly increased, especially under isosmotic conditions, resulting in an enhanced expression of the NFAT5 target gene heat shock protein 70 (HSP70). Further analysis revealed that the increase of NFAT5 activity depended primarily on an enhanced activity of the c-terminal transactivation domain (TAD), while NFAT5 protein abundance was largely unaffected. Enhanced activity of the TAD is probably mediated

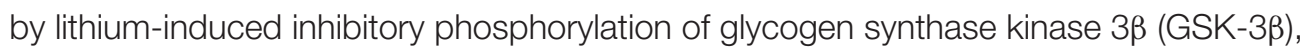
which is in accordance with previous studies. When cells were exposed to lithium for a longer period (96h), cellular NFAT5 activity and subsequently expression of HSP70 significantly decreased under hyperosmotic conditions, due to diminished NFAT5 protein abundance, also resulting from GSK-3 $\beta$ inhibition. Taken together, our results provide evidence that lithium has opposing effects on NFAT5 activity, depending on environmental osmolality and exposure duration. The potential impacts of these observations on the diverse effects of lithium on kidney function are discussed.

\section{Keywords: NFAT5, lithium, nephrogenic diabetes insipidus, GSK3ß, urinary concentrating mechanism, chronic} kidney disease

\section{Introduction}

The beginning of the widespread use of lithium as a mood stabilizer in the treatment of bipolar disorders in the early 1970s also saw the first reports of adverse renal side effects accompanying lithium treatment. The most common adverse effect is nephrogenic diabetes insipidus (NDI), due to a decreased expression of the aquaporin-2 (AQP-2) water channel and incorrect trafficking of AQP-2 to the luminal membrane in collecting duct cells (Marples et al., 1995; Kwon et al., 2000). Lithium-induced NDI, affecting up to $40 \%$ of all patients, can be detected within a few weeks after beginning lithium administration (Grünfeld and Rossier, 2009). 
Additionally, patients receiving lithium for more than 10 years have a significantly increased risk of developing chronic kidney disease (CKD; Bendz et al., 2010).

Lithium affects multiple molecular targets and signaling pathways, making it difficult to characterize the exact mechanisms by which the positive effects on the mood of psychiatric patients or the renal side effects are induced. In the last two decades, however, it has become increasingly evident that inhibition of the glycogen synthase kinase $3 \beta$ (GSK-3 $\beta$; Klein and Melton, 1996; Stambolic et al., 1996) plays a crucial role for the effects of lithium both in neuronal and kidney cells. GSK-3 $\beta$ is a ubiquitiously expressed serine/threonine kinase with multiple downstream targets, often transcriptional regulators (Doble and Woodgett, 2003). Under "normal" (non-stimulated) conditions GSK-3 $\beta$ is in its active state. In most cases, phosphorylation by active GSK-3 $\beta$ suppresses the activity of its downstream targets. Under stimulated conditions, phosphorylation of a serine residue (Ser9 in mouse, Ser21 in human) inactivates GSK-3 $\beta$, thereby activating downstream targets.

Recently, the osmosensitive transcription factor nuclear factor of activated T-cells 5 [NFAT5, also known as tonicity enhancer binding protein (TonEBP) or osmolality response element binding protein (OREBP)] has been identified as GSK-3 $\beta$ downstream target in renal cells (Zhou et al., 2013; Quadri and Siragy, 2014). NFAT5 is an osmosensitive transcription factor that serves two important functions in the renal medulla. First, it regulates the expression of osmoprotective genes, such as heat shock protein 70 (HSP70; Woo et al., 2002), aldose reductase (AR; Ko et al., 2000), taurine transporter (TauT; Zhang et al., 2003), sodium-myo-inositol transporter (SMIT; Miyakawa et al., 1999), or betain-gaba transporter 1 (BGT-1; Miyakawa et al., 1998), all of which are essential for cell survival under the hyperosmotic conditions of the renal medulla. Second, NFAT5 (together with other factors) regulates the expression of components of the urinary concentration machinery, such as AQP-2 (Lam et al., 2004; Hasler et al., 2006), or the urea transporter-1 (UTA; Nakayama et al., 2000). Accordingly, animal studies have demonstrated that inhibition or downregulation of NFAT5 in the kidney is associated with urinary concentration defects (Lam et al., 2004) and severe renal damages (López-Rodríguez et al., 2004). Generally, activation of NFAT5 in response to hyperosmotic stress is mediated by an increase of NFAT5 protein abundance (Miyakawa et al., 1999) and by activation of the c-terminal transactivation domain (TAD; Ferraris et al., 2002), which in turn stimulates the transcriptional machinery. The regulation of NFAT5 activity is a complex process, and various kinases, in addition to GSK-3 $\beta$, are reportedly involved, among them p38 (Ko et al., 2002), AKT (Roth et al., 2010), or phosphoinositide-3 kinase (PI-3K; Irarrazabal et al., 2006). Under isosmotic conditions GSK-3 $\beta$ is active and suppresses NFAT5 activation (the exact phosphorylation site within NFAT5 has not yet been identified). High osmolality activates AKT, PKA, and PI-3K, which in turn inhibit GSK-3 $\beta$, resulting in enhanced activity of the c-terminal TAD of NFAT5 (Zhou et al., 2013).

The aim of the present study was to evaluate the effects of lithium on the activity of NFAT5. We present evidence for two opposing effects: short exposure enhances NFAT5 activity by stimulation of the c-terminal TAD, while long exposure decreases NFAT5 activity due to diminished protein abundance.

\section{Methods}

\section{Materials}

Antibodies were obtained as follows: anti-NFAT5 antibody was from Santa Cruz Biotechnology (Santa Cruz, CA, USA); anti-actin antibody was from Sigma (Deisenhofen, Germany); anti-phospho-GSK-3 $\beta$ (Ser9), anti-GSK-3 $\beta$, anti-phospho-p38 (Thr180/Tyr182), and anti-p38 were purchased from Cell Signaling (Beverly, MA, USA); anti-phospho-Akt (Ser473) and anti-AKT were from Genscript (Piscataway, NJ, USA). GSK$3 \beta$ inhibitor VIII was obtained from Cayman Chemical (Ann Arbor, MI, USA). Unless otherwise indicated, other reagents were purchased from Biomol (Hamburg, Germany), Biozol (Eching, Germany), Carl Roth (Karlsruhe, Germany), or Sigma.

\section{Cell Culture}

HEK293 or IMCD-3 cells were cultured in Dulbeccos modified Eagles medium supplemented with $10 \%$ fetal bovine serum (Biochrom, Berlin, Germany), 100 units/ml penicillin, and $100 \mu \mathrm{g} / \mathrm{ml}$ streptomycin (Invitrogen, Karlsruhe, Germany) at $37^{\circ} \mathrm{C}$ in a humidified atmosphere $\left(95 \%\right.$ air $\left./ 5 \% \mathrm{CO}_{2}\right)$. Cells were grown in 24-well plates to confluency. For experiments, medium osmolality was increased by addition of $\mathrm{NaCl}$. Lithium was added to the medium as $\mathrm{Li}_{2} \mathrm{SO}_{4}$, in concentrations of 1-10 mM; control cells were treated with corresponding concentrations of $\mathrm{Na}_{2} \mathrm{SO}_{4}$. GSK-3 $\beta$ inhibitor VIII, dissolved in DMSO, was used at a final concentration of $10 \mu \mathrm{M}$.

\section{qRT-PCR Analysis}

For determination of mRNA expression levels, total RNA from IMCD-3 cells was recovered using TriFast Reagent (Peqlab, Erlangen, Germany) according to the manufacturer's recommendations. The primers (Metabion, Martinsried, Germany) used in these experiments were:
HSP70_fw: $5^{\prime}$-tga gtc cca cac tct cac ca- $3^{\prime}$;
HSP70_rev: $5^{\prime}$-ctg tgg gtg aag ctg tta agg $-3^{\prime}$;
NFAT5_fw: 5'-AAT CGC CCA AGT CCC TCT AC-3';
NFAT5_rev: 5'-GGT GGT AAA GGA GCT GCA AG -3'; actin_fw: $5^{\prime}$ - CCA ACC GCG AGA AGA TGA-3'; actin_rev: 5' - CCA GAG GCG TAC AGG GAT AG -3' .

Experiments were performed on a CFX Connect Real Time PCR Detection System (BioRad, Hercules, CA, USA) using the SensiMix SYBR One-Step Kit (Bioline, Luckenwalde, Germany) according to the manufacturer's recommendations. Relative mRNA expression of the respective genes was calculated by the $2^{-\Delta \Delta C T}$-method (Livak and Schmittgen, 2001), using $\beta$-actin as housekeeping gene. Specificity of PCR product formation was confirmed by monitoring melting point analysis and by agarose gel electrophoresis.

\section{Immunoblot Analysis}

Aliquots of cell extracts from IMCD-3 cells (5-30 $\mu$ g protein) were subjected to sodium dodecylsulphate polyacrylamide gel 
electrophoresis (SDS-PAGE) and blotted onto nitrocellulose membranes (GE Healthcare, Pittsburgh, PA, USA). Non-specific binding sites were blocked with $5 \%$ non-fat dry milk in phosphate-buffered saline (PBS) containing 0.1\% Tween-20 (PBS-T) at room temperature for $1 \mathrm{~h}$. Samples were incubated with primary antibodies in PBS-T containing 5\% non-fat dry milk over night at $4^{\circ} \mathrm{C}$. Subsequently, the blots were washed three times with PBS-T for $5 \mathrm{~min}$ each, and the membranes incubated with appropriate secondary antibody at room temperature for $1 \mathrm{~h}$ in PBS-T containing 5\% non-fat dry milk. After washing with PBS-T three times for $5 \mathrm{~min}$ each, immunocomplexes were visualized by enhanced chemiluminescence.

\section{Determination of NFAT5 Cellular Activity}

NFAT5 transcriptional activity was assessed using the secreted alkaline phosphatase system (SEAP) with a reporter construct in which the SEAP open reading frame is under control of two TonE sites. Generation of stably transfected HEK293-pSeapTonE cells is described elsewhere (Neuhofer et al., 2007). After growing to confluency, the cells were treated as indicated and SEAP activity in the medium determined as described in detail elsewhere (Neuhofer et al., 2007). In experiments in which cells were exposed for $96 \mathrm{~h}$ to the respective stimulus, medium was changed after $72 \mathrm{~h}$ to ensure that SEAP activity in the medium reflects the actual NFAT5 cellular activity.

\section{Determination of NFAT5 Transactivating Activity}

NFAT5 transactivating activity in HEK293 cells was determined using the Gal4 binary assay as described elsewhere (Ferraris et al., 2002; Küper et al., 2012). Gal4-TonEBP-TAD contains the yeast Gal4 DNA binding domain fused in-frame to the TAD of NFAT5 [amino acids 548-1531; kindly provided by Dr. J. Ferraris (NIH, Bethesda, MD, USA)]. pFR-SEAP (Agilent, Santa Clara, CA, USA) contains five tandem repeats of the Gal4 binding site upstream of a minimal promoter and the SEAP ORF. Briefly, $4 \times 10^{6}$ cells were transfected by electroporation with $20 \mu \mathrm{g}$ pGal4-TonEBP-TAD and $20 \mu \mathrm{g}$ pFR-SEAP (350 V, $950 \mu \mathrm{F} ; 4 \mathrm{~mm}$ cuvette) using a Genepulser Xcell apparatus (Bio-Rad), and subsequently plated into $4-6$ wells of a 24 -well plate. After 24$48 \mathrm{~h}$, the cells were treated as indicated and SEAP activity in the medium was determined as described above.

\section{Statistical Analyses}

Data are expressed as means \pm S.E.M. The significance of differences between the means was assessed by Student's $t$-test. $P<0.05$ was regarded as significant. All experiments were performed at least four times and representative results are shown.

\section{Results}

\section{Short-term Exposure to Lithium}

First, the effect of a short-term exposure to lithium on NFAT5 activity in renal cells was tested. For this purpose, IMCD-3 or HEK 293 cells were exposed to $10 \mathrm{mM} \mathrm{Li}_{2} \mathrm{SO}_{4}$ or $10 \mathrm{mM} \mathrm{Na}_{2} \mathrm{SO}_{4}$ (as control) for periods of $24 \mathrm{~h}$, under isosmotic $(300 \mathrm{mosm} / \mathrm{kg}$ $\left.\mathrm{H}_{2} \mathrm{O}\right)$ or hyperosmotic $\left(500 \mathrm{mosm} / \mathrm{kg} \mathrm{H}_{2} \mathrm{O}\right)$ conditions.

\section{Short-term Exposure to Lithium Increases Cellular NFAT5 Activity}

Cellular NFAT5 activity was measured in HEK 293 cells stably transfected with a TonE-driven reporter vector. Under isosmotic conditions a four-fold increase of reporter gene activity in response to lithium was observed, while under hypertonic conditions lithium caused a more moderate increase of reporter gene activity about 25\% (Figure 1). These data clearly indicate that lithium, especially under isosmotic conditions, stimulates basal cellular NFAT5 activity, but also slightly increases NFAT5 activity under hyperosmotic conditions.

\section{Lithium Increases Expression of the NFAT5 Target Gene HSP70}

To test the effect of increased cellular activity of NFAT5 on expression of NFAT5 target genes, mRNA and protein levels of HSP70 (as a representative NFAT5 target gene) were evaluated in IMCD-3 cells (Figures 2A-C). Expression of HSP70 under isosmotic conditions was enhanced severalfold compared with control cells. Under hyperosmotic conditions, lithium also increased expression of HSP70 (although the increase was less pronounced than under isosmotic conditions), consistent with the results of lithium-induced enhanced cellular NFAT5 activity.

\section{Cellular NFAT5 Activity Is Increased by Enhanced Activation of the TAD}

To determine the mechanism, by which lithium increases NFAT5 cellular activity, NFAT5 expression and TAD activity were assessed. NFAT5 expression was assessed in IMCD-3 cells at the mRNA and protein levels. As shown in Figure 2, hyperosmolality increased NFAT5 expression, as expected, but lithium had no significant influence on NFAT5 mRNA or protein levels. The activity of the C-terminal TAD of NFAT5 was measured in HEK 293 cells, transiently transfected with a binary reporter system. As shown in Figure 3, lithium increased basal TAD activity approximately three-fold under isosmotic conditions, compared with control cells. Also under hyperosmotic conditions, lithium also significantly increased TAD activity. These results clearly

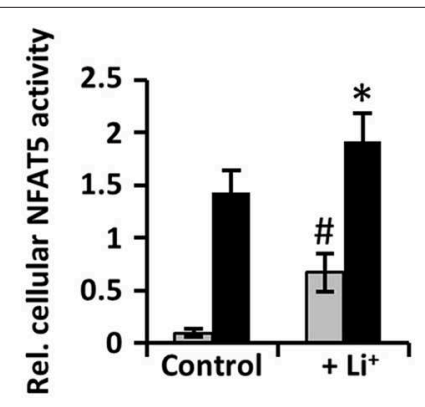

FIGURE 1 | Short-term exposure to lithium increases cellular NFAT5 activity. HEK 293 cells stably transfected with a reporter construct in which the SEAP gene is under control of two TonE sites were incubated for $24 \mathrm{~h}$ in isosmotic ( $; 300$ mosm $/ \mathrm{kg} \mathrm{H}_{2} \mathrm{O}$ ) or hyperosmotic $\left(\mathbf{\square} ; 500 \mathrm{mosm} / \mathrm{kg} \mathrm{H}_{2} \mathrm{O}\right.$ ) medium and exposed to $10 \mathrm{mM} \mathrm{Li}_{2} \mathrm{SO}_{4}$ or $10 \mathrm{mM} \mathrm{Na}_{2} \mathrm{SO}_{4}$ (as control). After $24 \mathrm{~h}, \mathrm{SEAP}$ activity was measured as described in Methods. Data are means \pm SEM for $n=6$; ${ }^{\star} P<0.05$ vs. hyperosmotic control; $\# P<0.05$ vs. isosmotic control. 
A

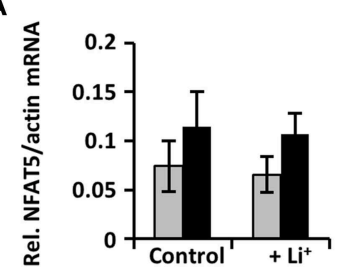

C

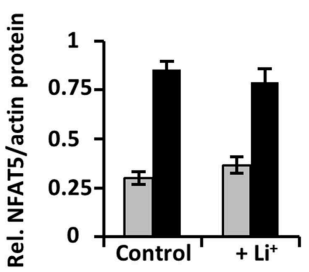

B

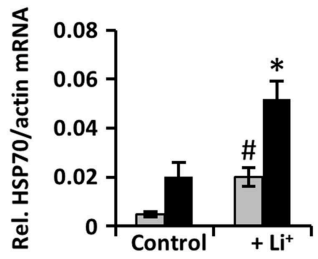

$300500300500 \mathrm{mosm} / \mathrm{kg} \mathrm{H}_{2} \mathrm{O}$

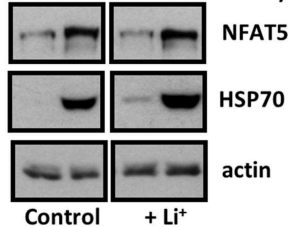

FIGURE 2 | Short-term exposure to lithium increases expression of the NFAT5 target gene HSP70. Confluent IMCD-3 cells were incubated for $24 \mathrm{~h}$ in isosmotic ( ; 300 mosm $/ \mathrm{kg} \mathrm{H}_{2} \mathrm{O}$ ) or hyperosmotic ( $\mathbf{\square} ; 500 \mathrm{mosm} / \mathrm{kg} \mathrm{H}_{2} \mathrm{O}$ ) medium and exposed to $10 \mathrm{mM} \mathrm{Li}_{2} \mathrm{SO}_{4}$ or $10 \mathrm{mM} \mathrm{Na} 2 \mathrm{SO}_{4}$ (as control). (A) Cells were processed for RNA extraction and the abundance of NFAT5 and HSP70 mRNA transcripts determined by qRT-PCR. Relative mRNA abundance was normalized to that of $\beta$-actin to correct for differences in RNA input. Data are means \pm SEM for $n=4 ;{ }^{\star} P<0.05$ vs. hyperosmotic control; \# $P<0.05$ vs. isosmotic control. (B) Cells were processed for immunoblotting. To demonstrate comparable protein loading, the blots were also probed for actin. A representative blot from four independent experiments is shown. (C) Relative protein abundance of NFAT5 and HSP70 was quantified by densitometric analysis of immunoblots and normalized to that of actin to correct for differences in protein loading. Data are means \pm SEM for $n=4$; ${ }^{\star} P<0.05$ vs. hyperosmotic control; $\# P<0.05$ vs. isosmotic control.

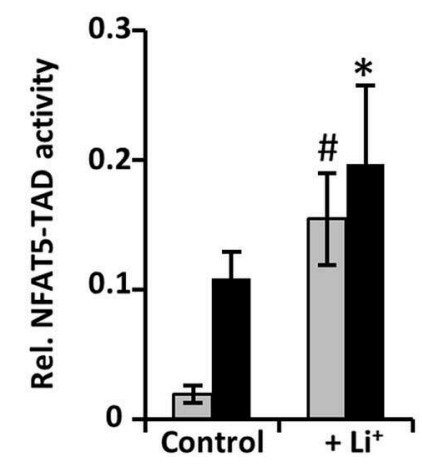

FIGURE 3 | Short-term exposure to lithium stimulates the transactivation domain of NFAT5. HEK 293 cells were electroporated with pGAL4-TonEBP-TAD and pFR-SEAP as described in Methods. Subsequently, cells were incubated for $24 \mathrm{~h}$ in isosmotic ( $;$; $300 \mathrm{mosm} / \mathrm{kg} \mathrm{H} \mathrm{H}_{2} \mathrm{O}$ ) or hyperosmotic $\left(\mathbf{\square} ; 500 \mathrm{mosm} / \mathrm{kg} \mathrm{H}_{2} \mathrm{O}\right.$ ) medium and exposed to $10 \mathrm{mM} \mathrm{Li}_{2} \mathrm{SO}_{4}$ or $10 \mathrm{mM} \mathrm{Na}_{2} \mathrm{SO}_{4}$ (as control). Thereafter, SEAP activity was determined as described in Methods. Data are means \pm SEM for $n=6$; ${ }^{\star} P<0.05$ vs. hyperosmotic control; \# $P<0.05$ vs. isosmotic control.

indicate that an enhanced transactivating activity is by far the most important mechanism for lithium-induced increase of cellular NFAT5 activity.

\section{Lithium Mediates Inhibitory Phosphorylation of GSK-3 $\beta$}

Next, we examined the effect of lithium on GSK-3 $\beta$ in IMCD-3 cells. Lithium induced an increase of inhibitory phosphorylation at Ser9, as shown in Figure 4A. We also tested phosphorylation status of the kinases AKT and p38, which have been previously shown to mediate inhibition of GSK-3 $\beta$ in renal cells under hyperosmotic conditions. We could not detect any substantial impact of lithium on AKT or p38 activity, under either isoor hyper-osmotic conditions. Time-course analysis revealed a relatively slow lithium-induced inhibitory phosphorylation of GSK-3 $\beta$, which reached its maximum after approximately $24 \mathrm{~h}$ (Figure 4B).

\section{Long-term Exposure to Lithium}

Additionally, the effect of prolonged exposure to lithium on NFAT5 activity in renal cells was examined. For this purpose, IMCD-3 or HEK 293 cells were again exposed to $10 \mathrm{mM} \mathrm{Li}_{2} \mathrm{SO}_{4}$ or $10 \mathrm{mM} \mathrm{Na}_{2} \mathrm{SO}_{4}$ (as control) under isosmotic $(300 \mathrm{mosm} / \mathrm{kg}$ $\mathrm{H}_{2} \mathrm{O}$ ) or hyperosmotic $\left(500 \mathrm{mosm} / \mathrm{kg} \mathrm{H}_{2} \mathrm{O}\right)$ conditions, this time for periods of $48-96 \mathrm{~h}$.

\section{Long-term Exposure to Lithium Decreases Cellular NFAT5 Activity under Hyperosmotic Conditions}

HEK 293 cells stably transfected with a TonE-driven reporter vector were incubated for $96 \mathrm{~h}$. Whilst still slightly enhanced under isosmotic conditions, reporter gene activity in response to lithium decreased dramatically under hyperosmotic conditions, compared with control cells (Figure 5A). These data clearly indicate that prolonged exposure to lithium suppresses cellular NFAT5 activity under hyperosmotic conditions.

\section{Long-term Exposure to Lithium Decreases Expression of NFAT5 and HSP70}

Next, expression of NFAT5 during long-term lithium exposure was assessed in IMCD-3 cells. While mRNA levels showed no significant differences compared to control cells (Figure 5B), NFAT5 protein abundance declined significantly after $48 \mathrm{~h}$, especially under hyperosmotic conditions, but also under 


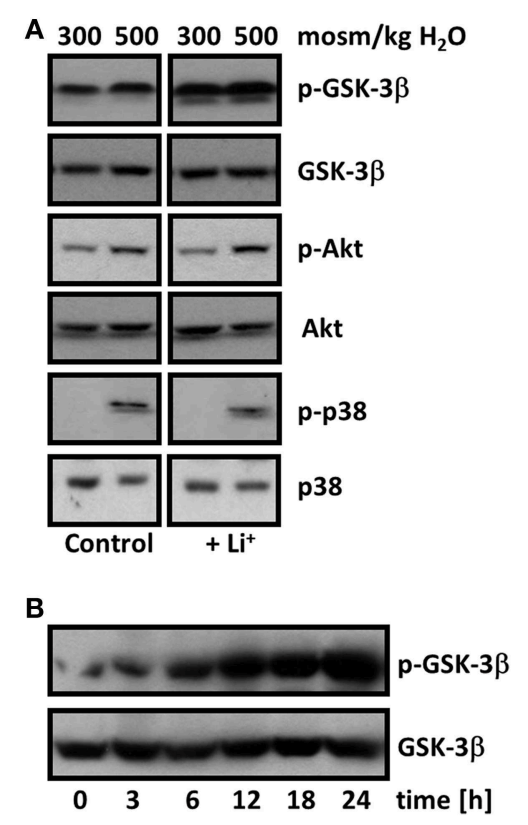

FIGURE 4 | Lithium mediates inhibitory phosphorylation of GSK-3 $\beta$. (A) Confluent IMCD-3 cells were incubated for $24 \mathrm{~h}$ in isosmotic $(300 \mathrm{mosm} / \mathrm{kg}$ $\mathrm{H}_{2} \mathrm{O}$ ) or hyperosmotic (500 mosm $/ \mathrm{kg} \mathrm{H}_{2} \mathrm{O}$ ) medium and exposed to $10 \mathrm{mM}$ $\mathrm{Li}_{2} \mathrm{SO}_{4}$ or $10 \mathrm{mM} \mathrm{Na}_{2} \mathrm{SO}_{4}$ (as control). Thereafter, cells were processed for immunoblotting and phosphorylation status of GSK-3 $\beta$, AKT, and p38 was determined as described in Methods. A representative blot from four independent experiments is shown. (B) Time-course of GSK-3 $\beta$ inhibitory phosphorylation. Confluent IMCD-3 cells were incubated for 0-24 $\mathrm{h}$ in isosmotic medium (300 mosm $/ \mathrm{kg} \mathrm{H}_{2} \mathrm{O}$ ) in the presence of $10 \mathrm{mM} \mathrm{Li}_{2} \mathrm{SO}_{4}$. Thereafter, cells were processed for immunoblotting and phosphorylation status of GSK-3 $\beta$ was determined as described in Methods. A representative blot from four independent experiments is shown.

isosmotic conditions; this decline was further enhanced after $96 \mathrm{~h}$ (Figures 5C,D). These results indicate that long-term exposure to lithium decreases NFAT5 expression and thereby cellular NFAT5 activity, probably mediated by posttranscriptional mechanisms.

Expression of the NFAT5 target gene HSP70 under isosmotic conditions was slightly enhanced compared with control cells, even after $96 \mathrm{~h}$. Under hyperosmotic conditions, HSP70 protein levels were significantly decreased after $96 \mathrm{~h}$ of exposure to lithium (Figures 5C,D). These results are consistent with the observed attenuation of cellular NFAT5 activity.

GSK-3 $\beta$ inhibitory phosphorylation by lithium was still stable after $96 \mathrm{~h}$ (data not shown).

\section{Pharmacological GSK-3 $\beta$ Inhibition Mimics the Effect of Lithium on NFAT5 Activity}

To determine whether lithium-induced downregulation of NFAT5 is mediated by GSK-3 $\beta$ inhibition, we also examined the effect of the specific pharmacological GSK-3 $\beta$ inhibitor VIII. Similar to lithium treatment, under hyperosmotic conditions both cellular NFAT5 activity (Figure 6A) and expression of NFAT5 and HSP70 (Figures 6B-D) were decreased significantly compared with control cells. Under isosmotic conditions, cellular NFAT5 activity and HSP70 expression in cells treated with
GSK-3 $\beta$ inhibitor VIII were also less than in control cells, in contrast to lithium treatment. We assume that an even stronger downregulation of NFAT5 by GSK-3 $\beta$ inhibitor VIII, compared with lithium, is responsible for this observation. Taken together, the results suggest that lithium-induced downregulation of NFAT 5 might be mediated by GSK-3 $\beta$ inhibition.

\section{Discussion}

The results presented in this study indicate that lithium has two opposing effects on NFAT5 activity in renal cells: in the first, "rapid" response to lithium exposure, NFAT5 activity increases. This increase is probably mediated by inhibition of GSK-3 $\beta$ and subsequent activation of the c-terminal TAD of NFAT5, while NFAT5 protein levels are largely unaffected. The group of Joan Ferraris showed recently that the TAD activity under isosmotic conditions is suppressed by GSK-3 $\beta$, and that under hyperosmotic conditions, inhibitory phosphorylation of GSK-3 $\beta$ (mediated by AKT, PKA, and PI-3K) interrupts this suppression (Zhou et al., 2013). The lithium-induced increase of NFAT5 activity was especially pronounced under isosmotic conditions. Normally, NFAT5 activity under isosmotic conditions is virtually zero, as illustrated by the minimal expression of the NFAT 5 target gene HSP70. Under these conditions, lithium increases NFAT5 activity and expression of HSP70 severalfold (however, still less than under hyperosmotic conditions). Under hyperosmotic conditions, the effect of lithium on NFAT5 activity is more moderate, probably since GSK-3 $\beta$ is already inhibited under these conditions, as mentioned above. An additional GSK$3 \beta$ inhibition by lithium only slightly enhances TAD activity (25-50\%).

When cells were exposed to lithium for prolonged periods (up to 96h), a second, "slow" response was observed: under hyperosmotic conditions, cellular NFAT5 activity and expression of NFAT5 target genes decreased, probably due to reduced NFAT5 protein abundance. The mechanisms, by which lithiuminduced inhibition of GSK-3 $\beta$ mediates NFAT5 downregulation, are not clear. Normally, NFAT5 protein abundance increases under hyperosmotic conditions, which, in addition to activation of TAD, contributes to enhanced cellular NFAT5 activity under these conditions. Enhanced transcription and increased mRNA stability have been identified as important mechanisms for hyperosmolality-induced upregulation of NFAT5 expression (Cai et al., 2005). Since NFAT5 mRNA levels were largely unaffected by prolonged exposure to lithium, we assume that translational or posttranslational mechanisms are probably responsible for the observed downregulation of NFAT5. Regulation of NFAT5 by such mechanisms has, to date, not been addressed in detail. In cardiac cells, doxorubicin induces ubiquitin-independent proteasomal degradation of NFAT5 protein (Ito et al., 2007), and recent investigations suggest that the long non-coding RNA "non-coding repressor of NFAT" (NRON) may be involved in proteasomal NFAT5 degradation (Umekita et al., 2013). We attempted to establish whether the proteasomal inhibitor MG132 influences lithium-induced degradation of NFAT5, but since exposure of IMCD-3 cells to the combination of hyperosmotic stress, lithium and MG-132 for periods longer than $24 \mathrm{~h}$ caused 
A

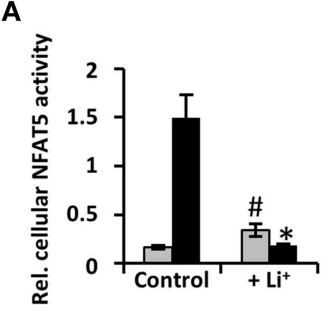

C

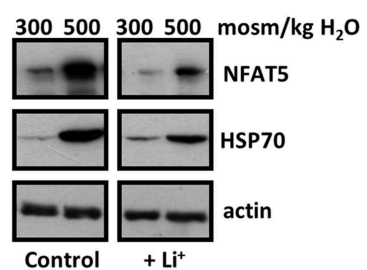

B

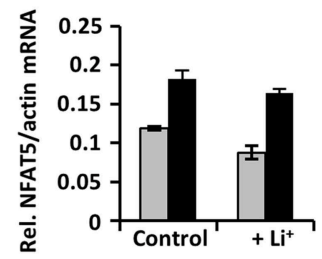

D

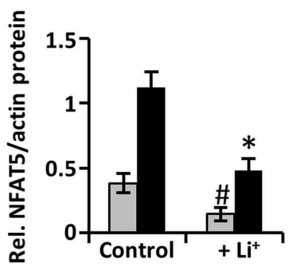

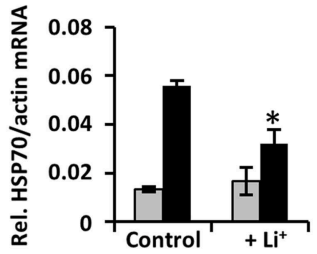

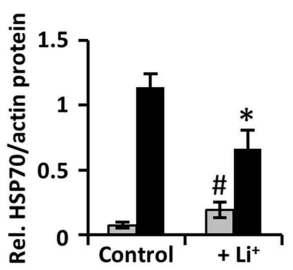

FIGURE 5 | Long-term exposure to lithium decreases cellular NFAT5 activity. HEK 293 cells stably transfected with a reporter construct in which the SEAP gene is under control of two TonE sites (A) or IMCD-3 cells (B-D) were incubated for $96 \mathrm{~h}$ in isosmotic ( $\left.; 300 \mathrm{mosm} / \mathrm{kg} \mathrm{H} \mathrm{H}_{2} \mathrm{O}\right)$ or hyperosmotic $(\mathbf{\square} ; 500 \mathrm{mosm} / \mathrm{kg}$ $\mathrm{H}_{2} \mathrm{O}$ ) medium and exposed to $10 \mathrm{mM} \mathrm{Li}_{2} \mathrm{SO}_{4}$ or $10 \mathrm{mM} \mathrm{Na}_{2} \mathrm{SO}_{4}$ (as control). (A) After $96 \mathrm{~h}$, SEAP activity was measured as described in Methods. Data are means \pm SEM for $n=6$; ${ }^{*} P<0.05$ vs. hyperosmotic control; $\# P<0.05$ vs. isosmotic control. (B) IMCD-3 cells were processed for RNA extraction and the abundance of NFAT5 and HSP70 mRNA transcripts was determined by qRT-PCR. Relative mRNA abundance was normalized to that of $\beta$-actin to correct for differences in RNA input. Data are means \pm SEM for $n=4$; ${ }^{*} P<0.05$ vs. hyperosmotic control; $\# P<0.05$ vs. isosmotic control. (C) IMCD-3 cells were processed for immunoblotting. To demonstrate comparable protein loading, the blots were also probed for actin. A representative blot from four independent experiments is shown. (D) Relative protein abundance of NFAT5 and HSP70 was quantified by densitometric analysis of immunoblots and normalized to that of actin to correct for differences in protein loading. Data are means \pm SEM for $n=4$; ${ }^{*} P<0.05$ vs. hyperosmotic control; $\# P<0.05$ vs. isosmotic control.

massive cell death, we were not able to obtain significant results (data not shown).

Of particular interest is the observation that the impact of prolonged lithium incubation (96 h) on NFAT5 activity also depends on environmental osmolality. As discussed above, NFAT5 activity and expression of target gene HSP70 clearly declines under hyperosmotic conditions. Under isosmotic conditions, however, NFAT5 activity in lithium treated cells is higher than in control cells, although NFAT5 protein abundance slightly decreased. We assume that, in sum, the strong stimulatory effect of lithium on TAD activity of NFAT5 overrides the decrease of NFAT5 protein, as also indicated by the increased expression of HSP70 under these conditions. Transferred to the situation in the kidney, these results indicate that the effect of lithium on NFAT5 activity depends not only on the duration of exposure but also on the kidney region. Cortical collecting duct cells are not usually exposed to hyperosmotic stress, hence, NFAT5 activity in this region may be enhanced even during longterm lithium treatment. In contrast, in collecting duct cells of the outer and especially the inner medulla, which are regularly exposed to hyperosmotic conditions, lithium probably decreases NFAT5 activity and expression of its target genes. Accordingly, a proteomic analysis demonstrated that expression of the NFAT5 target genes AR and HSP70 is significantly decreased in inner medullary collecting duct cells in lithium-treated rats (Nielsen et al., 2008).

The question arises as to whether altered NFAT5 activity contributes to the well-known renal side effects of lithium therapy. The molecular mechanisms underlying these side effects are not completely understood (Behl et al., 2015). Among these side effects, NDI is the most frequent, affecting up to $40 \%$ of lithium-treated patients. Lithium decreases AQP-2 expression and trafficking to the luminal membrane of the principal cells of the collecting duct. Moreover, the urea transporters UT-A and UT-B, which are necessary for efficient urea circulation in the kidney and hence for maximal urinary concentration ability, are downregulated by lithium in a rat model (Klein et al., 2002; Blount et al., 2010). NFAT5 has been identified as a positive regulator of AQP-2 (Kasono et al., 2005; Hasler et al., 2006) and UT-A (Nakayama et al., 2000) expression; additionally, the NFAT5 target gene AR has been linked to the urinary concentration mechanism (Aida et al., 2000). Accordingly, in a mouse model expressing a dominant-negative NFAT5 derivative, the urinary concentrating ability is decreased (Lam et al., 2004). In a rat model of sepsis-induced polyuria, inhibitory nitrosylation of NFAT5 is associated with decreased renal expression of AQP-2, UT-A1, ClC-K1 and its regulatory subunit barttin, also resulting in impaired urinary concentration ability (Küper et al., 2012). These data clearly indicate the importance of NFAT5 for urinary concentration, and thus it seems plausible that lithium-induced downregulation of NFAT5, at least in medullary collecting duct cells, contributes to the development of NDI during lithium treatment.

Long-term treatment with lithium ( $>10$ years) is also associated with an enhanced risk of developing CKD (Markowitz et al., 2000; Presne et al., 2003). The underlying mechanisms 

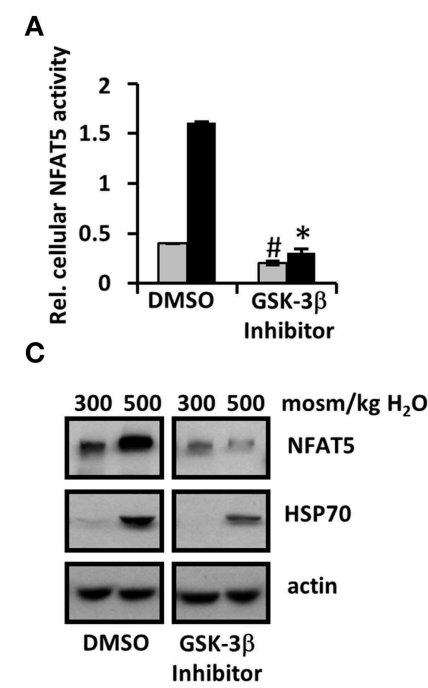

B

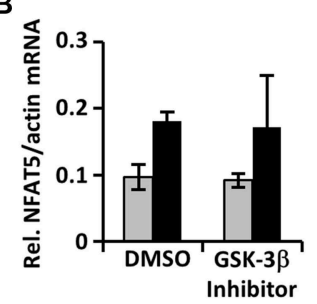

D

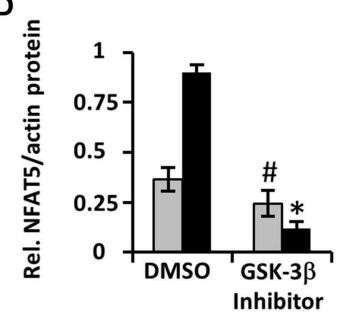

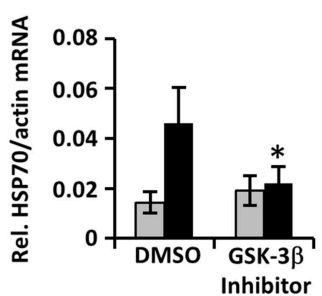

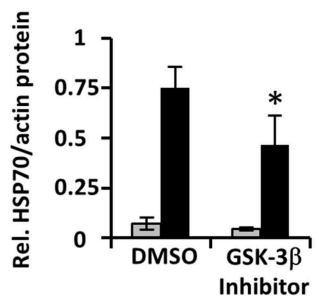

FIGURE 6 | GSK-3 $\beta$ inhibitor VIII mimics the effect of lithium on cellular NFAT5 activity. HEK 293 cells stably transfected with a reporter construct in which the SEAP gene is under control of two TonE sites (A) or IMCD-3 cells (B-D) were incubated for $96 \mathrm{~h}$ in isosmotic ( $\left.; 300 \mathrm{mosm} / \mathrm{kg} \mathrm{H} \mathrm{H}_{2} \mathrm{O}\right)$ or hyperosmotic ( $\mathbf{\square}$; 500 mosm $/ \mathrm{kg} \mathrm{H}_{2} \mathrm{O}$ ) medium in the presence of $10 \mu \mathrm{M}$ GSK-3 $\beta$ inhibitor VIII or vehicle DMSO (as control). (A) After $96 \mathrm{~h}$, SEAP activity was measured as described in Methods. Data are means \pm SEM for $n=6$; ${ }^{\star} P<0.05$ vs. hyperosmotic control; $\# P<0.05$ vs. isosmotic control. (B) IMCD-3 cells were processed for RNA extraction and the abundance of NFAT5 and HSP70 mRNA transcripts was determined by qRT-PCR. Relative mRNA abundance was normalized to that of $\beta$-actin to correct for differences in RNA input. Data are means \pm SEM for $n=4$; ${ }^{*} P<0.05$ vs. hyperosmotic control; $\# P<0.05$ vs. isosmotic control. (C) IMCD-3 cells were processed for immunoblotting. To demonstrate comparable protein loading, the blots were also probed for actin. A representative blot from four independent experiments is shown. (D) Relative protein abundance of NFAT5 and HSP70 was quantified by densitometric analysis of immunoblots and normalized to that of actin to correct for differences in protein loading. Data are means \pm SEM for $n=4 ;{ }^{*} P<0.05$ vs. hyperosmotic control; $\# P<0.05$ vs. isosmotic control.

are even less well understood than lithium-induced NDI, thus it is difficult to hypothesize whether downregulation of NFAT5 contributes to the very slow development of CKD. Since NFAT5 is an essential regulator for expression of several important osmoprotective genes it is easily imaginable that decreased NFAT5 activity might cause renal injury. Indeed, NFAT5 knockout mice develop severe renal damage (LópezRodríguez et al., 2004). However, to our knowledge there are, to date, no reports in the literature that clearly link decreased expression of one or more NFAT5 target genes to lithium-induced $\mathrm{CKD}$, thus this subject remains to be elucidated.

In contrast to these well-known adverse renal side effects of lithium, recent reports indicate that lithium might be useful for treatment of acute kidney injury (AKI). In animal models of ischemia/reperfusion- or toxin-induced AKI, lithium was protective against renal injury or improved recovery from AKI (Wang et al., 2009; Talab et al., 2010, 2012; Plotnikov et al., 2013; Bao et al., 2014). It has been shown before that upregulation of HSP70 can protect renal cells against ischemic injury (Aufricht et al., 1998; Yeh et al., 2010; Wang et al., 2011). Based on the results of the present study, one may speculate that short exposure to lithium increases NFAT5 activity in renal cells and thereby stimulates expression of HSP70 (and perhaps other target genes), which contribute to the protective effect of lithium against renal injury.
Can lithium alter cellular NFAT5 activity also in extrarenal tissues? When lithium is used therapeutically, serum levels of 0,4$1 \mathrm{mM}$ are recommended (National Institute for Health and Care Excellence, (NICE), 2006). In the present study, significant effects of lithium on NFAT5 activity in renal cells were only observed at relative high concentrations $\left(5-10 \mathrm{mM} \mathrm{Li}_{2} \mathrm{SO}_{4}\right.$, corresponding to $10-20 \mathrm{mM} \mathrm{Li}^{+}$). Due to the concentration mechanism of the nephron, lithium levels in the collecting duct fluid can exceed $20 \mathrm{mM}$ (Hayslett and Kashgarian, 1979; Birch and Hullin, 1980), indicating that the effects we observed in cell culture may also be relevant in vivo, at least in the distal nephron and the collecting duct. Based on our results, it seems unlikely that the comparatively low serum lithium levels will have a significant impact on NFAT5 activity in extrarenal cells. However, accumulation of lithium has also been observed in other tissues (Thomas et al., 1975; Mendlewicz et al., 1978; Costa et al., 1982; Kabakov et al., 1998), and thus lithium-mediated altered NFAT5 activity outside the kidney should not be completely ruled out.

\section{Acknowledgments}

Work in the authors' laboratory was supported by grants from the Deutsche Forschungsgemeinschaft, the Deutsche Nierenstiftung, the Münchener Medizinische Wochenschrift, and by the Friedrich Baur Stiftung, Munich. We thank Dr. John Davis for critical reading of the manuscript. The help of Maria-Luisa Fraek is gratefully acknowledged. 


\section{References}

Aida, K., Ikegishi, Y., Chen, J., Tawata, M., Ito, S., Maeda, S., et al. (2000). Disruption of aldose reductase gene (Akrlbl) causes defect in urinary concentrating ability and divalent cation homeostasis. Biochem. Biophys. Res. Commun. 277, 281-286. doi: 10.1006/bbrc.2000.3648

Aufricht, C., Lu, E., Thulin, G., Kashgarian, M., Siegel, N. J., and Van Why, S. K. (1998). ATP releases HSP-72 from protein aggregates after renal ischemia. Am. J. Physiol. 274, F268-F274.

Bao, H., Ge, Y., Wang, Z., Zhuang, S., Dworkin, L., Peng, A., et al. (2014). Delayed administration of a single dose of lithium promotes recovery from AKI. J. Am. Soc. Nephrol. 25, 488-500. doi: 10.1681/ASN.2013040350

Behl, T., Kotwani, A., Kaur, I., and Goel, H. (2015). Mechanisms of prolonged lithium therapy-induced nephrogenic diabetes insipidus. Eur. J. Pharmacol. 755, 27-33. doi: 10.1016/j.ejphar.2015.02.040

Bendz, H., Schön, S., Attman, P. O., and Aurell, M. (2010). Renal failure occurs in chronic lithium treatment but is uncommon. Kidney Int. 77, 219-224. doi: $10.1038 / \mathrm{ki} .2009 .433$

Birch, N. J., and Hullin, R. P. (1980). Lithium and the kidney. Br. Med. J. 280, 1148-1149. doi: 10.1136/bmj.280.6223.1148-b

Blount, M. A., Sim, J. H., Zhou, R., Martin, C. F., Lu, W., Sands, J. M., et al. (2010). Expression of transporters involved in urine concentration recovers differently after cessation of lithium treatment. Am. J. Physiol. Renal Physiol. 298, F601-F608. doi: 10.1152/ajprenal.00424.2009

Cai, Q., Ferraris, J. D., and Burg, M. B. (2005). High $\mathrm{NaCl}$ increases TonEBP/OREBP mRNA and protein by stabilizing its mRNA. Am. J. Physiol. Renal Physiol. 289, F803-F807. doi: 10.1152/ajprenal.00448.2004

Costa, J. L., Fay, D. D., Nurnberger, J. I., and Murphy, D. L. (1982). Preferential accumulation of lithium in the dense bodies of human platelets. Biochem. Pharmacol. 31, 3215-3218. doi: 10.1016/0006-2952(82)90552-4

Doble, B. W., and Woodgett, J. R. (2003). GSK-3: tricks of the trade for a multi-tasking kinase. J. Cell Sci. 116, 1175-1186. doi: 10.1242/jcs.00384

Ferraris, J. D., Williams, C. K., Persaud, P., Zhang, Z., Chen, Y., and Burg, M. B. (2002). Activity of the TonEBP/OREBP transactivation domain varies directly with extracellular $\mathrm{NaCl}$ concentration. Proc. Natl. Acad. Sci. U.S.A. 99, 739-744. doi: 10.1073/pnas. 241637298

Grünfeld, J. P., and Rossier, B. C. (2009). Lithium nephrotoxicity revisited. Nat. Rev. Nephrol. 5, 270-276. doi: 10.1038/nrneph.2009.43

Hasler, U., Jeon, U. S., Kim, J. A., Mordasini, D., Kwon, H. M., Féraille, E., et al. (2006). Tonicity-responsive enhancer binding protein is an essential regulator of aquaporin-2 expression in renal collecting duct principal cells. J. Am. Soc. Nephrol. 17, 1521-1531. doi: 10.1681/ASN.2005121317

Hayslett, J. P., and Kashgarian, M. (1979). A micropuncture study of the renal handling of lithium. Pflugers Arch. 380, 159-163. doi: 10.1007/BF00582152

Irarrazabal, C. E., Burg, M. B., Ward, S. G., and Ferraris, J. D. (2006). Phosphatidylinositol 3-kinase mediates activation of ATM by high $\mathrm{NaCl}$ and by ionizing radiation: role in osmoprotective transcriptional regulation. Proc. Natl. Acad. Sci. U.S.A. 103, 8882-8887. doi: 10.1073/pnas.0602911103

Ito, T., Fujio, Y., Takahashi, K., and Azuma, J. (2007). Degradation of NFAT5, a transcriptional regulator of osmotic stress-related genes, is a critical event for doxorubicin-induced cytotoxicity in cardiac myocytes. J. Biol. Chem. 282, 1152-1160. doi: 10.1074/jbc.M609547200

Kabakov, A. Y., Karkanias, N. B., Lenox, R. H., and Papke, R. L. (1998). Synapsespecific accumulation of lithium in intracellular microdomains: a model for uncoupling coincidence detection in the brain. Synapse 28, 271-279.

Kasono, K., Saito, T., Saito, T., Tamemoto, H., Yanagidate, C., Uchida, S., et al. (2005). Hypertonicity regulates the aquaporin-2 promoter independently of arginine vasopressin. Nephrol. Dial. Transplant 20, 509-515. doi: 10.1093/ndt/gfh677

Klein, J. D., Gunn, R. B., Roberts, B. R., and Sands, J. M. (2002). Down-regulation of urea transporters in the renal inner medulla of lithium-fed rats. Kidney Int. 61, 995-1002. doi: 10.1046/j.1523-1755.2002.00210.x

Klein, P. S., and Melton, D. A. (1996). A molecular mechanism for the effect of lithium on development. Proc. Natl. Acad. Sci. U.S.A. 93, 8455-8459. doi: 10.1073/pnas.93.16.8455

Ko, B. C., Lam, A. K., Kapus, A., Fan, L., Chung, S. K., and Chung, S. S. (2002). Fyn and p38 signaling are both required for maximal hypertonic activation of the osmotic response element-binding protein/tonicity-responsive enhancerbinding protein (OREBP/TonEBP). J. Biol. Chem. 277, 46085-46092. doi: $10.1074 /$ jbc.M208138200

Ko, B. C., Turck, C. W., Lee, K. W., Yang, Y., and Chung, S. S. (2000). Purification, identification, and characterization of an osmotic response element binding protein. Biochem. Biophys. Res. Commun. 270, 52-61. doi: 10.1006/bbrc. 2000.2376

Küper, C., Fraek, M. L., Muller, H. H., Beck, F. X., and Neuhofer, W. (2012). Sepsisinduced urinary concentration defect is related to nitric oxide-dependent inactivation of TonEBP/NFAT5, which downregulates renal medullary solute transport proteins and aquaporin-2. Crit. Care Med. 40, 1887-1895. doi: 10.1097/CCM.0b013e31824e1186

Kwon, T. H., Laursen, U. H., Marples, D., Maunsbach, A. B., Knepper, M. A., Frokiaer, J., et al. (2000). Altered expression of renal AQPs and $\mathrm{Na}(+)$ transporters in rats with lithium-induced NDI. Am. J. Physiol. Renal Physiol. 279, F552-F564.

Lam, A. K., Ko, B. C., Tam, S., Morris, R., Yang, J. Y., Chung, S. K., et al. (2004). Osmotic response element-binding protein (OREBP) is an essential regulator of the urine concentrating mechanism. J. Biol. Chem. 279, 48048-48054. doi: $10.1074 /$ jbc.M407224200

Livak, K. J., and Schmittgen, T. D. (2001). Analysis of relative gene expression data using real-time quantitative PCR and the 2(-Delta Delta C(T)) Method. Methods 25, 402-408. doi: 10.1006/meth.2001.1262

López-Rodríguez, C., Antos, C. L., Shelton, J. M., Richardson, J. A., Lin, F., Novobrantseva, T. I., et al. (2004). Loss of NFAT5 results in renal atrophy and lack of tonicity-responsive gene expression. Proc. Natl. Acad. Sci. U.S.A. 101, 2392-2397. doi: 10.1073/pnas.0308703100

Markowitz, G. S., Radhakrishnan, J., Kambham, N., Valeri, A. M., Hines, W. H., and D'Agati, V. D. (2000). Lithium nephrotoxicity: a progressive combined glomerular and tubulointerstitial nephropathy. J. Am. Soc. Nephrol. 11, 1439-1448.

Marples, D., Christensen, S., Christensen, E. I., Ottosen, P. D., and Nielsen, S. (1995). Lithium-induced downregulation of aquaporin-2 water channel expression in rat kidney medulla. J. Clin. Invest. 95, 1838-1845. doi: 10.1172/JCI117863

Mendlewicz, J., Verbanck, P., Linkowski, P., and Wilmotte, J. (1978). Lithium accumulation in erythrocytes of manic-depressive patients: an in vivo twin study. Br. J. Psychiatry 133, 436-444. doi: 10.1192/bjp. 133.5.436

Miyakawa, H., Woo, S. K., Chen, C. P., Dahl, S. C., Handler, J. S., and Kwon, H. M. (1998). Cis- and trans-acting factors regulating transcription of the BGT1 gene in response to hypertonicity. Am. J. Physiol. 274, F753-F761.

Miyakawa, H., Woo, S. K., Dahl, S. C., Handler, J. S., and Kwon, H. M. (1999). Tonicity-responsive enhancer binding protein, a rel-like protein that stimulates transcription in response to hypertonicity. Proc. Natl. Acad. Sci. U.S.A. 96, 2538-2542. doi: 10.1073/pnas.96.5.2538

Nakayama, Y., Peng, T., Sands, J. M., and Bagnasco, S. M. (2000). The TonE/TonEBP pathway mediates tonicity-responsive regulation of UTA urea transporter expression. J. Biol. Chem. 275, 38275-38280. doi: 10.1074/jbc.M004678200

Neuhofer, W., Steinert, D., Fraek, M. L., and Beck, F. X. (2007). Prostaglandin E2 stimulates expression of osmoprotective genes in MDCK cells and promotes survival under hypertonic conditions. J. Physiol. 583, 287-297. doi: 10.1113/jphysiol.2007.135178

National Institute for Health and Care Excellence, (NICE) (2006). "Bipolar disorder: the management of bipolar disorder in adults, children and adolescents, in primary and secondary care," in Clinical Guideline 38.

Nielsen, J., Hoffert, J. D., Knepper, M. A., Agre, P., Nielsen, S., and Fenton, R. A. (2008). Proteomic analysis of lithium-induced nephrogenic diabetes insipidus: mechanisms for aquaporin 2 down-regulation and cellular proliferation. Proc. Natl. Acad. Sci. U.S.A. 105, 3634-3639. doi: 10.1073/pnas.08000 01105

Plotnikov, E. Y., Grebenchikov, O. A., Babenko, V. A., Pevzner, I. B., Zorova, L. D., Likhvantsev, V. V., et al. (2013). Nephroprotective effect of GSK3beta inhibition by lithium ions and delta-opioid receptor agonist dalargin on gentamicin-induced nephrotoxicity. Toxicol. Lett. 220, 303-308. doi: 10.1016/j.toxlet.2013.04.023 
Presne, C., Fakhouri, F., Noël, L. H., Stengel, B., Even, C., Kreis, H., et al. (2003). Lithium-induced nephropathy: rate of progression and prognostic factors. Kidney Int. 64, 585-592. doi: 10.1046/j.1523-1755.2003.00096.x

Quadri, S., and Siragy, H. M. (2014). Regulation of (pro)renin receptor expression in mIMCD via the GSK-3beta-NFAT5-SIRT-1 signaling pathway. Am. J. Physiol. Renal Physiol. 307, F593-F600. doi: 10.1152/ajprenal.00245.2014

Roth, I., Leroy, V., Kwon, H. M., Martin, P. Y., Féraille, E., and Hasler, U. (2010). Osmoprotective transcription factor NFAT5/TonEBP modulates nuclear factor-kappaB activity. Mol. Biol. Cell 21, 3459-3474. doi: 10.1091/mbc.E1002-0133

Stambolic, V., Ruel, L., and Woodgett, J. R. (1996). Lithium inhibits glycogen synthase kinase- 3 activity and mimics wingless signalling in intact cells. Curr. Biol. 6, 1664-1668. doi: 10.1016/S0960-9822(02)70790-2

Talab, S. S., Elmi, A., Emami, H., Nezami, B. G., Assa, S., Ghasemi, M., et al. (2012). Protective effects of acute lithium preconditioning against renal ischemia/reperfusion injury in rat: role of nitric oxide and cyclooxygenase systems. Eur. J. Pharmacol. 681, 94-99. doi: 10.1016/j.ejphar.2012. 01.042

Talab, S. S., Emami, H., Elmi, A., Nezami, B. G., Assa, S., Deroee, A. F., et al. (2010). Chronic lithium treatment protects the rat kidney against ischemia/reperfusion injury: the role of nitric oxide and cyclooxygenase pathways. Eur. J. Pharmacol. 647, 171-177. doi: 10.1016/j.ejphar.2010.08.036

Thomas, R. C., Simon, W., and Oehme, M. (1975). Lithium accumulation by snail neurones measured by a new Li+-sensitive microelectrode. Nature 258, 754-756. doi: 10.1038/258754a0

Umekita, K., Trenkmann, M., Kolling, C., Michel, B. A., Gay, R. E., Gay, S., et al. (2013). Long noncoding RNA Nron regulates the cytoplasmic-nuclear shuttling and activity of NFAT5 in rheumatoid arthritis synovial fibroblast [Abstract]. Arthritis Rheum. 65(Suppl. 10):2872. doi: 10.1002/art.2013.65.issue-s10

Wang, Y., Huang, W. C., Wang, C. Y., Tsai, C. C., Chen, C. L., Chang, Y. T., et al. (2009). Inhibiting glycogen synthase kinase-3 reduces endotoxaemic acute renal failure by down-regulating inflammation and renal cell apoptosis. $\mathrm{Br}$. J. Pharmacol. 157, 1004-1013. doi: 10.1111/j.1476-5381.2009.00284.x

Wang, Z., Gall, J. M., Bonegio, R. G., Havasi, A., Hunt, C. R., Sherman, M. Y., et al. (2011). Induction of heat shock protein 70 inhibits ischemic renal injury. Kidney Int. 79, 861-870. doi: 10.1038/ki.2010.527

Woo, S. K., Lee, S. D., Na, K. Y., Park, W. K., and Kwon, H. M. (2002). TonEBP/NFAT5 stimulates transcription of HSP70 in response to hypertonicity. Mol. Cell. Biol. 22, 5753-5760. doi: 10.1128/MCB.22.16.57535760.2002

Yeh, C. H., Hsu, S. P., Yang, C. C., Chien, C. T., and Wang, N. P. (2010). Hypoxic preconditioning reinforces HIF-alpha-dependent HSP70 signaling to reduce ischemic renal failure-induced renal tubular apoptosis and autophagy. Life Sci. 86, 115-123. doi: 10.1016/j.lfs.2009.11.022

Zhang, Z., Ferraris, J. D., Brooks, H. L., Brisc, I., and Burg, M. B. (2003). Expression of osmotic stress-related genes in tissues of normal and hyposmotic rats. Am. J. Physiol. Renal Physiol. 285, F688-F693. doi: 10.1152/ajprenal.00028.2003

Zhou, X., Wang, H., Burg, M. B., and Ferraris, J. D. (2013). Inhibitory phosphorylation of GSK-3beta by AKT, PKA, and PI3K contributes to high $\mathrm{NaCl}$-induced activation of the transcription factor NFAT5 (TonEBP/OREBP). Am. J. Physiol. Renal Physiol. 304, F908-F917. doi: 10.1152/ajprenal.00591.2012

Conflict of Interest Statement: The authors declare that the research was conducted in the absence of any commercial or financial relationships that could be construed as a potential conflict of interest.

Copyright (C) 2015 Küper, Beck and Neuhofer. This is an open-access article distributed under the terms of the Creative Commons Attribution License (CC BY). The use, distribution or reproduction in other forums is permitted, provided the original author(s) or licensor are credited and that the original publication in this journal is cited, in accordance with accepted academic practice. No use, distribution or reproduction is permitted which does not comply with these terms. 